\title{
Non-state actors in global environmental governance: New arrangements beyond the state
}

\author{
Bas $\operatorname{Arts}^{1}$
}

[This chapter will be published in a 2005 Palgrave volume on global governance, edited by M. Koenig-Archibugi and M. Zürn]

\section{Introduction}

Many theorists on globalization and global governance - for example Held, McGrew, Rosenau, Keohane, Nye, Strange, and others - observe an increasing role for non-state actors (NSAs) in the global arena. To some of them, the concept of governance itself expresses exactly this phenomenon: namely an increase of private and civil actor involvement in the global arena, implying a transition from 'government' to 'governance'. With that, political power has become (much?) more diffused in the global system. This chapter builds on these observations and arguments, however focusing on the environmental domain.

Empirically, the chapter will present three cases: (1) the regime on biodiversity (including biosafety), (2) standard-setting for environmental management systems, and (3) the establishment of forest certification programs. With these cases, we witness (more or less) involvement of different types of non-state actors in global environmental governance (GEG), exercising political power in various qualities and quantities. Consequently, we observe different levels of publicness, inclusiveness and delegation - the three analytical dimensions of global governance put central in this volume - in various environmental policy arrangements.

The choice of these three cases may seem rather arbitrary. And they are to some extent (expertise of author). Yet they represent an interesting sample from GEG, as one case is characterized by state dominance (biodiversity), another by market dominance (environmental management systems) and the final one by civil society dominance (forestry) (although all three are in fact 'mixed-actor constellations'). In terms of substance, there is an interesting variety as well, one case from the 'grey' domain (industrial pollution), two from the 'green' (biodiversity and forestry). Also, two are definitely trade-related (forestry and industrial pollution), one less so (biodiversity). Besides the delineation of cases, there is also a restriction regarding NSAs. Whereas the concept refers to several categories of players, from terrorists to scientists and churches, this chapter focuses on two of them: NGOs (or civic pressure groups) and business players (or private interest groups). The reason to do so is the fact that these two groups constitute powerful lobbies in many international environmental negotiations and they have proven to be able to design regulatory systems in the environmental domain themselves.

The structure of this chapter is as follows. First, I will go into some relevant theories on (global) governance. Special attention will be paid to the role and power of non-state actors (NSAs). Secondly, I proceed with a section on global environmental governance (GEG) itself. There it will be argued that the environmental domain is a sector par excellence to study new

\footnotetext{
${ }^{1}$ Dr. B.J.M. Arts is Associate Professor in international environmental politics at the Nijmegen School of Management, Radboud University Nijmegen, the Netherlands.
} 
modes of governance. Thirdly, the three cases will be presented and analyzed in subsequent sections, including an assessment of publicness, delegation and inclusiveness. Finally, I will draw some conclusions.

\section{Global Governance}

The concept

The buzzword of the late 1990s and early 2000s in political sciences, public administration and management sciences alike is the concept of governance (Held and McGrew, 2002; Héritier, 2001, 2002; Hooghe and Marks, 2001; Pierre, 2000; Van Kersbergen and Van Waarden, 2001). To most, it refers to a 'paradigm shift' in the way we govern (post)modern societies and organizations. Due to processes such as 'relocation of politics' (from the state to international and sub-national organizations), 'de-territorialization' (the emergence of new political spaces beyond the territorial nation state), 'diffusion of political power' (from public authorities to semi-public and private actors) and 'de-legitimization of the state' (crisis of the welfare state, state failures, lack of performance), the old 'paradigm' of top-down, state-led, command \& control ways of steering do no longer suffice (Bovens et al., 1995; Dubbink, 1999; Hajer, 2000). Instead, we find new forms of governance and policy instruments: network-like arrangements of public and private actors, self-regulation by business organizations, public-private and civic-private partnerships, emission trading schemes, certification programs, etc (Kickert et al., 1997; Kolk, 2000; Meidinger, 2002; Bendell, 2000). Some refer to this as a 'shift from government to governance' or as 'governance without government' (Rosenau and Czempiel, 1992; Van Kersbergen and Van Waarden, 2001).

However, the concept of governance is contested, for several reasons. The first one is that it can mean a lot. For example, Heritier (2001) distinguishes two meanings, Pierre (2000) three, Hirst (2000) five, Rhodes (2000) seven and Van Kersbergen and Van Waarden (2001) eight. Analytically, however, one may distinguish between 'old', 'new' and 'all' types of governance (Knill and Lehmkuhl, 2002; Pierre, 2000). 'Old' refers to state steering, 'new' to innovative modes of governance, and 'all' to both categories. Normatively, one may add a fourth category, namely the promotion of a renewal of public and/or private management under the banner of governance. Examples are new public management (NPM), good governance and corporate governance. It should be noted that this chapter conceptually builds on the third category (see * in Table 1).

\begin{tabular}{|l|l|}
\hline Conceptualization & \multicolumn{2}{|l|}{ Meaning } \\
\hline 'Old' governance & $\begin{array}{l}\text { 'state steering' } \\
\text { (top-down, command \& control) }\end{array}$ \\
\hline 'New' governance & $\begin{array}{l}\text { 'new modes of governance' } \\
\text { (from public-private networks to private self- } \\
\text { regulation) }\end{array}$ \\
\hline 'All' governance* & $\begin{array}{l}\text { 'co-ordination mechanisms to provide for public } \\
\text { goods' } \\
\text { (either public, private or mixed) }\end{array}$ \\
\hline 'Normative' governance & $\begin{array}{l}\text { 'programs to renew public or private } \\
\text { management' } \\
\text { (good governance, NPM, corporate governance) }\end{array}$ \\
\hline
\end{tabular}

Table 1: Four conceptualizations of governance 
A second reason why the concept of governance is contested is its lack of theorizing about power and the state (Gilpin, 2002; Hewson and Sinclair, 1999). Too easily, relationships between public and private actors in different arenas and at different levels of policy-making are considered 'free of power games'. If politics are to be placed on a continuum between 'rationality' and 'power', which is often done so, then the governance literature is definitely at the 'rational side'. Another criticism concerns the role, power and transformation of the nation state, which remain under-theorized. All too often, it is (implicitly) assumed that an increase of (new) governance practices is accompanied by a 'retreat of the state' or 'an hollowing-out of the state' (Albrow, 1996; Pierre, 2000; Strange, 1996; Van Kersbergen et al., 1999). Although it is certainly the case that the state has (partly) retreated from certain domains, like economic or environmental policy, this claim cannot be hold true in general. As Hirst (2000) makes clear, the state remains dominant in those fields where it is traditionally considered 'the sovereign', such as the legitimate monopolization of collective violence, internal and external security, taxation \& currency, law and order and social consensusbuilding (although we may observe some shifts in these fields too, like UN peace forces, private armies, the introduction of the Euro, and private initiatives to maintain law and order in neighborhoods). Even more so, the power of the state has increased in some instances, the Internet being an example (Knill and Lehmkuhl, 2002). All this points at the fact that we do not witness a general retreat of the state, in the light of governance, but a transformation of the state.

\section{Global governance}

In the study of international relations (SIR), the concept of governance has become popular too and is generally referred to as 'global governance' (Nye \& Donahue, 2000; Held \& McGrew, 2002). In this domain, it has a slightly different meaning and has provoked some other debates, because the international system lacks a central authority anyway, so that we always deal with 'governance without government' (Rosenau and Czempiel, 1992). Yet some make similar distinctions as in the above, for example distinguishing between two meanings of global governance, one 'restricted', referring to only new governance, and one 'broad', referring to all modes of public co-ordination, either 'classical hierarchical' or 'post-modern bottom-up' (Heritier, 2001).

The concept of global governance has provoked specific criticism too. For example, neorealists have argued that this literature does not rightly understand and conceptualize the nature of the international system, which is anarchic and conflictual in nature and, as a consequence, dominated by (big) states (Gilpin, 2002). In turn, global governance theorists have argued that neo-realist overlook the fact that the nature of the state system is transcending from an 'anarchic society of states' to (the first traces of) a 'civic world society', in which several 'spheres of authority' (SOAs) can be distinguished, both territorially and functionally (Held \& McGrew, 2002; Rosenau, 2000).

\section{Non-state actors}

Most conceptualizations of global governance include the (potential) relevance of so-called non-state actors - NGOs, firms, epistemic communities, etc. - for governing global issues. Even more so, most approaches consider NSAs as being internal, not external, to the global governance system. This position not only transcends state-centred approaches, such as neorealism, but also the classical transnationalist view on international politics, in which NSAs are considered to be external, influential lobbyists at best (Reinalda, 1997). However, formally and informally, NSAs are ever more part of, and giving shape to, international networks of governance. 
Non-state actors (NSAs) are all those actors that are not (representatives of) states, yet that operate at the international level and that are potentially relevant to international relations (based on: Arts et al., 2001; Furtak, 1997; Higgot et al., 2000). Generally, five groups of NSAs are distinguished in the literature: 1. Intergovernmental Organizations (IGOs) ${ }^{2}, 2$. International Non-Governmental Organizations (INGOs), 3. Corporate Interest Groups (CIGs) and Transnational Corporations (TNCs), 4. Epistemic Communities (ECs) and 5. a remainder category (including terrorist networks, professional organizations, scouts, churches, etc.). As said in the introduction, this chapter focuses on two of these groups: INGOs and CIGs/TNCs. Following Thomas-Feraru (1974), INGOs are all those international non-profit, non-violent pressure groups that pursue certain public goals and that seek to influence outcomes in international politics. Examples are Greenpeace International, Oxfam International, Amnesty International, WWF and Pax Christi.

The question is, however, whether Corporate Interest Groups are part of this INGO definition or should be separately dealt with. Literally they are part, because organisations such as the International Chamber of Commerce and the World Business Council for Sustainable Development are themselves not profit-oriented (although their members are). Moreover, they are non-violent, pursue public goals (e.g. economic development) and seek to influence international politics. Ideologically and functionally, however, these pressure groups are quite different. Therefore the distinction is made between NGOs (Civic Pressure Groups) on the one hand and BINGOs (Business NGOs, or Corporate Interest Groups) on the other.

A TNC can be defined as any large-scale, profit-making, commercial organisation, with offices and/or production units in many countries around the world (Dicken, 1988). Examples are Shell, BP, Ford, GM, Unilever, McDonalds, IBM, Microsoft, Deloitte and Touche, etc. Today, there are some 37,000 TNCs operative in the international political economy (Higgots et al., 2000). Generally, these firms themselves do not participate in politics, but the BINGOs that represent their interests do (see previous paragraph). Today, there is nonetheless a trend that individual firms ever more further their interests in international arenas themselves, now they have for example standing rights in international bodies such as the EU and WTO (De Bievre, 2002).

\section{Global governance arrangements}

In the above, it was argued that NSAs are considered internal to the global rule system by the governance literature. This is not to say that all global governance arrangement are necessarily transnational in nature (such would also contrast our 'broad' definition of governance). Koenig-Archibugi (2002; this volume), for example, distinguishes a number of ideal-types of global governance arrangements, based on the degree of 'publicness' (public nature of actors and interactions involved), 'delegation' (the extent to which authority is shifted from states to autonomous bodies) and 'inclusiveness' (access to and division of decisional power). As a consequence, arrangements may be more or less intergovernmental in nature (states dominant), supranational (one international organization dominant), hegemonic (one state dominant), transnational (private actors dominant) and monopolistic (one private actor dominant). In addition, governance arrangements may be more or less directly governed by states and/or private actors, depending on the extent of delegation (minimal delegation = direct governance; maximum delegation $=$ indirect governance). Below, in the case studies,

\footnotetext{
${ }^{2}$ Not all would agree that an IGO is an NSA. Some consider an IGO simply as an ensemble of states, thus being a state actor, others believe that IGOs exhibit at least some degree of autonomy and authority vis-à-vis states, thus constituting a non-state actor.
} 
we will use these dimensions and categorizations to analyze the way in which different global governance arrangements are shaped.

\section{Global environmental governance}

It is generally assumed that globalization is fed by economic, political and socio-cultural developments (Dicken, 1998; Waters, 1995). Yet the environment is also an important driving force (Mol, 2001; Yearley, 1996). There are a number of reasons for this. First, the globe can be considered one interrelated web of ecosystems, although this view is contested (Lovelock, 1979). But whatever one might think of Gaia theory, the world is probably as ecologically interdependent as it is economically or politically. Second, many environmental problems are not limited to the territories of individual states, but - in contrast - transboundary in nature. One might think of water or air pollution, which call for international co-operation to mitigate or solve these issues (Bouwer, 1985). Third, the 1980s have witnessed the emergence of the so-called new, global environmental problems, such as climate change. These have challenged governments to co-operate even at a global scale (Rowlands, 1995). Fourth, transport facilities have accelerated the global diffusion of products and services, which might be harmful for the environment. One might think of cars and refrigerators, but also of 'genetically modified organisms' (GMOs) (Held \& McGrew, 2002). Finally, there is a lot of nature that exist outside the jurisdiction of national states. These are called 'the commons' the atmosphere, oceans, Antarctica - which need their own international rule systems for conservation and sustainable use (Caldwell, 1990).

According to many scholars, the development of global environmental governance (GEG) was initiated in 1972, although UN organizations had already been involved in the preservation of nature, the conservation of natural resources and the management of pollution before the 1970s (McCormick, 1989; Caldwell, 1990; Hurrell and Kingsbury, 1992; Vig and Axelrod, 1999). In that year the United Nations Conference on the Human Environment (UNCHE) was held in Stockholm (Sweden). This meeting produced a declaration, an action plan, and a new UN body: the United Nations Environment Programme (UNEP). More significantly however, the UNCHE became the starting point for a large number of initiatives at the global level, such as multilateral environmental treaties, of which more than 150 exist today (Rowlands, 1995). In addition, many international organizations and forums - such as G7, OECD, WTO, IMF, etc. - have put the issue of the environment on their agendas since the early 1970s (Vig and Axelrod, 1999).

However, public interest in environmental issues was subject to strong fluctuations (Weiss and Gordenker, 1996). The late 1970s witnessed a sharp decrease due to oil crises, economic stagnation and high unemployment rates. Also, the doom scenarios of many environmentalists were increasingly criticized. Yet the environmental issue unexpectedly re-appeared on the agenda in the mid-1980s, for several reasons. The world economy was doing better in this period, new environmental issues had come up - such as the greenhouse effect and the hole in the ozone layer - and new initiatives were undertaken by UN bodies. For example, the World Commission on Environment and Development (WCED), headed by Gro Harlem Brundtland, was established in the early 1980s and produced the famous report Our Common Future in 1987 (WCED, 1987). Since its publication, sustainable development has become one of the

buzzwords in the international community. Furthermore, the Brundtland report foreshadowed the United Nations Conference on Environment and Development. When this UNCED was held in Rio de Janeiro in June 1992, the environmental issue was high on the international 
agenda again. Since then it has abated somewhat, though not as dramatically as in the late 1970s.

According to several authors, the environmental domain has been a laboratory for new modes of governance par excellence, nationally and internationally (Driessen and Glasbergen, 2002; Meidinger, 2002; Van Tatenhove et al., 2000; Weale, 1992). Here we can observe all kind of experiments with self-regulation by business, target group policies, co-governance in networks, tradable emission permits, eco-taxes, co-venants, soft law, open co-ordination mechanisms, interactive projects, participatory policy-making, regional contracts, deliberative democracy, green alliances between business and NGOs, and the like. Although global environmental policies have been 'laggards' in this regard, compared to national and European ones, new modes of governance have been slowly but certainly introduced (Vig and Axelrod, 1999). Below we will go into three examples more in-depth.

\section{Biodiversity Convention \& Biosafety Protocol: an 'intermediate' governance arrangement}

The notion of biodiversity brings together different areas of concern: (1) endangering and extinction of species; (2) destruction and loss of ecosystems; and (3) genetic engineering and erosion. These issues are covered by the UNEP Framework Convention on Biological Diversity (CBD), adopted at the UNCED in Rio de Janeiro in 1992 and signed and ratified by more than 150 countries. It aims at nature conservation, on the one hand, and at the sustainable use of biological resources, on the other (Glowka et al., 1994). It also contains Article 19(3) on biosafety, dealing with the need for a safe transfer, handling and use of genetically modified organisms (GMOs). As an elaboration of this article, the Cartagena Protocol on Biosafety (CPB) was adopted in Montreal, Canada, January 2000 (Depledge, 2000).

The origin of the biodiversity convention goes back to discussions in the World Conservation Union (IUCN), which is the leading international nature conservation organization (Burhenne-Guilmin and Casey-Lefkowitz, 1992; Glowka et al., 1994). Although both private organizations and governments may become members of IUCN, it is to be considered a nonstate actor, as the private organizations dominate the governance structure (Willetts, 1986). In the beginning of the 1980s, the concepts of 'nature' and 'nature conservation' - often related to species only - were discussed in the IUCN. It was felt that a 'discursive renewal' was needed in order to be able to incorporate the 'new issues' of genetic engineering and habitat destruction. The notion of 'biodiversity', ever more used by biologists at that time, seemed to be an appropriate concept for this purpose.

Besides this conceptual innovation, IUCN felt that new policy initiatives were needed as well, such as the launching of a global biodiversity convention. Subsequently, some of IUCN's commissions and experts prepared draft articles for such a global treaty. In 1987 the United Nations Environment Programme (UNEP), pressurized by the IUCN, also recognized the need for such a global instrument. In February 1991 formal negotiations among governments started in the UN Intergovernmental Negotiating Committee (INC). This INC met five times before the text of the UNEP Framework Convention on Biological Diversity (CBD) could be agreed upon. Almost all countries around the world participated in this process. 
The text of the CBD can be considered a delicate balance and complex compromise between Northern and Southern preferences, assets and interests (Arts, 1994). Whereas most developed countries aimed at a nature conservation treaty, under the banner of the CBD, many developing countries pushed a developmental agenda. Besides, the former wanted to have access to the biological resources of the poor, e.g. in tropical rain forests, whereas the latter wanted to have (cheaper) access to the (bio-)technology of the rich. As a consequence, the convention has been based on the idea of sustainable development on the one hand and an exchange of (conditional) access to biological resources and (bio)technology on the other.

Besides countries, several non-state actors (NSAs) impacted the outcome of the CBD negotiations. During this intergovernmental process, many NGOs - besides IUCN participated in policy and decision making (for as far as UN rules allowed such): WWF, Birdlife International, Biodiversity Action Network, World Resources Institute, GRAIN, Friend of the Earth, Greenpeace, RAFI, and others. According to empirical research (Arts, 1998), there are a number of issues that were particularly influenced by these NGOs: (1) some CBD principles (e.g. on the intrinsic value of biodiversity); (2) some articles on nature conservation measures in the treaty; and (3) the issues of marine biodiversity and indigenous people. This influence was mainly exercised by lobbying, scientific consultation and advice, public pressure and by organizing so-called Global Forums on Biodiversity, for which governmental representatives were invited.

As already referred to, the Cartagena Protocol on Biosafety was added to the CBD in 2000 (and entred into force in 2003). It mainly deals with the safe import and export of 'Genetically Modified Organisms' (GMOs) (although the CPB speaks of 'Living Modified Organisms', or LMOs, as GMOs turned out to be too much of a contested concept). The Protocol addresses: (1) an Advance Informed Agreement (AIA) procedure, which includes a 'right to know' for the country of import; (2) provisions on types of information to be provided by the country of export; (3) emergency measures for accidents; (4) socio-economic 'measures' (considerations) to compensate for the probable negative effects of the release of LMOs on local societies; and (5) the use of the precautionary principle (Depledge, 2000).

During the process of negotiating the protocol, many countries were sharply divided over the issue of biosafety, and as a result, different negotiation groups were formed (Arts and Mack, 2003; Depledge, 2000). Among the developing countries, the African Group called for strict procedures for trade in GMOs and propagated an environmental and precautionary approach. In contrast, Argentina, Chile and Uruguay supported the so-called 'Miami Group'. This USled group of countries shared the common interest of being major agricultural exporters and hosts to core biotech industries. Consequently, the group had no interest in concluding a treaty which would impose GMO regulations on them, and which would - from their perspective negatively affect their commercial agricultural and biotech industries. The EU took a sort of middle of the road position: a precautionary approach indeed, but not too strict regulations. These different positions are reflected in the Cartagena Protocol itself. Just as the CBD, it expresses a complex and delicate balance of different preferences, interests and assets.

It is claimed that NSAs from different sides - NGOs, BINGOs and individual firms - had an impact on this protocol too. As far as the NGOs is concerned, organizations such as IUCN, Greenpeace, WWF, Friends of the Earth and Third World influenced the contents of the protocol, notably the inclusion of the precautionary principle, the broadening of the protocol's scope and the inclusion of socio-economic considerations (although it should be realized that they could do so by working closely with 'like-minded' governments, such as several from 
Africa and the EU) (Arts and Mack, 2003). At the same time, however, the biotech industry was able to affect the CPB as well. Compared to earlier negotiations on the Biodiversity Convention, this was a rather new phenomenon, as industry had been more or less absent in this arena before. Now, with the design of biosafety regulations, there was something at stake for business. Its involvement grew rapidly in the negotiations, with for example 8 industry groups present in 1996 and more than 20 in 1999 (Clapp, 2002). In addition, individual TNCs, such as Monsanta and DuPont, closely followed and addressed the negotiations. The BINGOs were also able to form one umbrella organization, the Global Industry Coalition, to put more pressure on the final talks in Montreal in 2000. To further its interests, it closely co-operated with the so-called 'Miami Group'. In the end, this coalition of industry and 'conservative' countries was able to water down many of the initial proposals. For example, GMOs were redefined as LMOs, the AIA-procedure was weakened, CPB-regulations were made subject to WTO-regulations (although NGOs do not share this interpretation of the text), the precautionary principle was linked to scientific risk assessment and, finally, not any concrete liability regulation was taken up in the instrument.

So far we mainly dealt with the substance of biodiversity and biosafety as well as with the role of NSAs in their definition and policy elaboration. As far as the institutional design of the regime is concerned, its initiators and participants built a structure, which is very common in the 'framework convention \& protocol approach' (Hurrell and Kingsburry, 1992; Vig and Axelrod, 1999). First, a Conference of Parties (CoP) was established, which consist of all country parties to the convention and protocol and which is the main decisional body. This body meets (bi)annual. Second, there is a Secretariat, which supports the CoP to execute its tasks. Third, Committees on scientific advise and implementation have been designed, to resolve scientific questions and monitor implementation and compliance. Fourth, the negotiators formulated procedures for dispute settlement. And finally, procedures have been established to regulate the participation of (BI)NGOs. Given this institutional structure, it should be noted that no strong, independent and autonomous global body on biodiversity/biosafety has been designed, which has legislative, executive and juridical authority. Governments remain the key rule-makers, policy implementers and dispute settlers. Yet they are influenced and affected by NSAs, formally and internally (through CBD/CPB arrangements) as well as informally and externally (through public and market pressures).

To conclude this section, we should answer the question with what type of arrangement we are dealing with here. As far as publicness is concerned, it has become obvious that the group of active participants is heterogenous, both governmental and non-governmental in nature (with the group of (BI)NGOs involved growing over time). However, this does not imply equal power relations. Formal decision-making is still in the hands of governments, which becomes obvious when final decisions are taken or whenever political conflicts among governments arise. Then (BI)NGOs are generally excluded from taking part in the discussions (negotiations behind 'closed doors'). Therefore, inclusiveness is still limited. Practically, however, there exist an immense resource dependency among governments and (BI)NGOs. IUCN for example has a lot more knowledge on nature conservation than the average country delegation. The same goes for BINGOs and firms with regard to knowledge on biotechnology. As a consequence, the informal inclusiveness is a lot more substantial. The third criterion to assess the nature of a global governance arrangement, delegation, shows that the CBD and CPB do not delegate a lot of authority and autonomy to global bodies. Of course, governments did install the 'normal' institutions of framework conventions - CoPs, committees, dispute settlement procedures, consultative mechanisms - but their functioning is highly dependent on the general consent of governments. 
In sum, the global governance arrangement of biodiversity/biosafety is a mixture of (formal) 'global intergovernmentalism' and (informal) 'direct global transnationalism' (for these categorizations: see Koenig-Archibugi, 2002). Although the former characteristic is still dominant, the latter seems growing in importance

\section{Environmental Management Systems: examples of 'monopolist' governance arrangements}

Since the late 1980s and early 1990s, industry has taken ever more so-called 'voluntary initiatives' in the field of environmental management. Examples are environmental codes of conduct, publication of environmental reports, design of environmental management systems and establishment of environmental standards (Kolk, 2000). In this section, a combination of the latter two issues will be dealt with: the standardization of environmental management systems (EMSs) within and by industry (and other organizations) at the global level. Two examples will be dealt with: Responsible Care Initiative (RCI) and ISO 14001.

An environmental management system (EMS) is an organizational approach to environmental management (Goetsch and Davis, 2001; 2000; Kolk, 2000). It refers to that part of an organization's overall management system that addresses the environmental aspects of its operation, and which lead to an increase of environmental performance. Moreover, it should lead to continual improvement in environmental performance. The origin of these systems mainly lay in the USA, and to a lesser extent in Europe, in the 1980s (Steger, 2000). Pressed by environmental regulations, compliance difficulties, liability for bad performance, 'public shaming' for incidents, and litigation by public authorities and civilians, US companies themselves started to streamline, structure and systematize their environmental policies in order to have better results. In Europe, companies did similar things, but for other reasons. They hoped to gain new market opportunities as a response to the 'green consumerism' wave in Europe those days (late 1980s, early 1990s). In the beginning, individual companies 'invented' their own EMS, but later on, experiences were shared, industrial associations started to formulate guidelines, as did international organizations and governments. With that, global standardization of EMSs began.

The Responsible Care Initiative (RCI) is a global standard for the chemical industry, of which most are big TNCs. It concerns the safe and environmental sound management of chemicals throughout their life cycle (Gunninghan et al., 1999). ${ }^{3}$ Although global in its reach today, CRI had been locally designed, namely by the Canadian Chemical Producers' Associations (CCPA) in the late 1980s, in the aftermath of the Bhopal tragedy in India in 1984 (thousands of people died or were heavily injured due to an explosion in a chemical plant of Union Carbide). However, the CRI's origin goes back to the late 1970s, when guiding principles for the management of hazardous chemicals were endorsed (O'Connor, 2002). Also, projects on responsible care and product stewardship were executed in the early 1980s, however lowprofile and behind the scenes. But Bhopal tremendously speeded things up. In no time, public trust in the chemical industry dramatically dropped and both civilians and politicians asked whether similar accidents could happen everywhere, also in Canada. The response of the CCPA was to review its safety and emergency programmes on the one hand and their Public Relations (PR) and communication programmes on the other. Both were adjusted and integrated, by which the first contours of the RCI emerged. Finally, it was publicly announced

\footnotetext{
${ }^{3}$ Other sources: www.ccpa.ca; www.americanchemistry.com; www.icca-chem.org
} 
in spring 1986. It consists of, amongst others, a Responsible Care Ethic (six principles on stewardship, accountability, respect for people, continuous improvement, respect for the law and inspiration to third parties), a Community-Right-To-Know Policy (informing and communicating with the public), and six Codes of Practice (community awareness and emergency response, research and development, manufacturing, transportation, distribution and hazardous waste management). ${ }^{4}$ Also, certification and verification procedures have been installed to award firms with a certificate and to monitor implementation and compliance. These procedures should involve third parties (independent audit organizations as well as stakeholders). Today, RCI is adopted by 47 national associations of chemical industries, which implies that RCI is compulsory for their members. ${ }^{5}$

ISO 14001 is also an EMS standard, however not designed by and for a specific industrial sector, such as the chemical industry. It has developed in the context of the International Organization for Standardization (ISO), which is a hybrid NGO, similar to IUCN (Goetsch and Davis, 2001). The standard applies to many different sectors and types of organizations, including industry. Its history and origin are quite complex. Its roots go back to individual initiatives of firms in the 1980s, initiatives by industrial sectors (like Responsible Care), the design of national EMS standards in the early 1990s (such as the BS 7750 in the UK), older ISO standards on which could be built (such as ISO 9000 on Quality Management), as well as the preparation of the UN Earth Summit, or UNCED, to be held in Rio de Janeiro, Brazil, in 1992 (Goetsch and Davis, 2001; Kolk, 2000). The International Organization for Standardization (ISO) also participated in the UNCED process and, stimulated by it, started to consider the need for developing an international EMS standard. In 1993, it created Technical Committee 207, which designed the ISO 14000 family (including 14001). Like many other EMSs, ISO 14001 is based on the premise of continual improvement. As is the case for RCI, independent certification and auditing procedures have been designed. Yet, ISO 14001 does not set environmental goals nor does it oblige parties to report their performance to the larger public ('environmental reporting'). For these reasons, critics believe that it is a weak system from an ecological point of view (Seger, 2000). In terms of global diffusion, however, ISO 14001 is a success. Today, it is a common feature in about 125 countries around the world and more than 65,000 organizations (mainly companies) possess a certificate. ${ }^{6}$

Although both the Responsible Care Initiative (RCI) and ISO 14001 are EMSs and share several commonalities, they are different as well. On the one hand, RCI transcends ISO 14001 , as it also includes the adoption of certain substantive principles (on safety, health and the environment), the reckoning of product stewardship, and the establishment of community dialogue. On the other hand, ISO 14001 transcends RCI, as it is not restricted to industrial organizations nor to one sector. Secondly, empirical research indicates that ISO 14001 did have at least some practical consequences in (Dutch) chemical firms, whereas RCI remained a rather vague, high-level business philosophy at best (Weterings, forthcom.). Independent certification and verification also seem much better settled in the case of ISO than in the case of RCI. Thirdly, we are dealing with different regulatory systems here (Gunninghan et al., 1999). RCI builds on a system of 'self-regulation', which is a process whereby an organized group regulates the behaviour of its members. ISO 14001, in contrast, builds on a regulatory system of 'voluntarism'. Not associations, but individual organizations are the main subject, so that (environmental) initiatives are taken unilaterally and voluntary. Despite these differences, initiatives are nonetheless underway to combine both EMSs (at least in the

\footnotetext{
${ }^{4}$ Source: www.ccpa.ca

${ }^{5}$ Source: $\underline{\text { www.icca-chem.org }}$

${ }^{6}$ Sources: www.iso14000.com; www.iso.org.
} 
USA). ${ }^{7}$ What is called Responsible Care 14001 combines ISO 14001 and Responsible Care and allows participating organizations to gain accredited certificates for both Environmental Management Systems in a single audit.

The above seems to point at private initiatives in which governments and intergovernmental organizations (IGOs) do not play any role. This is correct for RCI. However, the situation regarding ISO 14001 is a bit different. Here the role of governments has been more extensive. Firstly, ISO 14001 grew out of the UNCED process, which was (mainly) an intergovernmental initiative (see section 3). Secondly, although ISO is a hybrid NGO of national standardization organizations, governments dominate these in some countries (Goetsch and Davis, 2001). And thirdly, ever more governments (try to) link ISO 14001 to their own environmental policy, by granting some 'regulatory relief' to those firms, which have installed, or will install, an EMS (Gunninghan et al., 1999).

Given the above developments and characteristics concerning the global governance of environmental management systems in firms, with what type of arrangement are we dealing with? As far as publicness is concerned, it has become obvious that this criterion is minimal in both cases. The group of active participants we deal with is rather homogenous and only private in nature (associations and firms). However, the role of governments in ISO 14001 is still substantial, but even here private actors have been the main initiators. Inclusiveness, secondly, seems rather minimal too, at least in terms of division of decision-making power. It were central agencies - CCPA en ISO - which designed these instruments. Yet national standardization organizations did play a role in the design of ISO 14001. In contrast, RCA was designed by one agency only, although international and national associations of chemical industries caught up during the elaboration and improvement of RCI the last decade. Another difference is the nature of the rule system: 'voluntarism' (ISO) versus 'binding selfregulation' (RCI). Given this different nature of regulation, the latter EMS is organized in a more 'hierarchical mode' than the former, with less inclusion as a consequence. In terms of access, though, inclusiveness seems rather substantial. In principle, all professional organizations are eligible to ISO 14001, whereas all members of chemical associations which endorse RCI are obliged to follow these rules. Also, there is a tendency to include as much as 'outsiders' in environmental management systems as possible, in order to create one level playing field and to endorse environmental reputation in the whole production chain (Steger, 2000). Yet most members are in fact western TNCs, both in case of RCI and ISO. High costs and limited market opportunities - particularly outside the West - do probably play a role here. Delegation, next, is present in both cases. Independent agencies are granted authority to certify and audit firms, in order to monitor the functioning of the EMS on the one hand and the continual improvement of environmental performance on the other, with an eye on awarding, maintaining or withdrawing the certificate concerned. Yet independent certification and auditing procedures are better designed and guaranteed in the case of ISO than in the case of RCI, the latter being much more dependent on self-monitoring.

To conclude, both RCI and ISO 14001 most resemble an 'indirect monopolist global governance arrangement' (for this categorization: see Koenig-Archibugi, 2002). Yet the former also exhibit some traces of 'direct monopolism' (dominant role of CCPA and the practice of self-monitoring), whereas the latter does so with regard to 'global intergovernmentalism' (governmental use of and influence in ISO).

\footnotetext{
${ }^{7}$ Source: www.americanchemistry.com
} 


\section{Forest stewardship council: a 'transnational' governance arrangement}

The issue of deforestation hit the international political agenda in the early 1980s (Humphreys, 1994). At that time it became clear that for several reasons - commercial logging, cultivation of agrarian lands, mining activities, building of infrastructure, lack of forest regulations, large-scale burning, unjust land rights, etc. - huge areas of forests had disappeared. Special attention drew the tropical forests, and the region of Amazonia in Brazil in particular. Figures (although always contested) pointed at an area of forests of the size of the Benelux which disappeared in this region each year (Kolk, 1996). Later on, unsustainable forest management practices in other countries (Canada, Ivory Coast, Russia) and other types of 'endangered' forests (boreal forests, ancient forests in general) became part of the agenda.

These problems led to a number of responses. First, NGOs like Greenpeace, WWF and the World Rainforest Movement started world-wide campaigns to stop these practices. Second, timber importing and exporting countries established the International Timber Trade Organisation (ITTO) in 1986, to deal with trade problems as well as environmental issues, and launched the voluntary ITTO 2000 target. This target aimed at basing the entire global timber trade on sustainable forest management practices in the year 2000, but obviously failed (Kern et al., 2001). In addition, attempts of NGOs to collaborate with the ITTO, for example on a forest certification program, were not successful too, as this intergovernmental organization was reluctant to co-operate with NGOs. And thirdly, governments in the United Nations decided that a global forest treaty to enhance conservation and sustainable management should be decided upon. However, this initiative also became a failure, due to fierce contradictions between developed and developing countries, the former emphasizing the need to conserve (tropical) forests, the latter the need to exploit them for economic reasons (Humphreys, 1994).

In the meantime, given these regulatory failures, several environmental organizations had expressed their wish to do business with industry on sustainable forestry themselves. As one NGO-leader said: "You cannot just sit back and wait for governments to agree, because this could take forever" (Bendell, 2000, p. 69). For example WWF started a dialogue with industry under the slogan Forests are your business in the UK in 1991 (Bendell, 2000). At global level, similar developments - dialogues between NGOs and industry - took place. In 1993, 150 organizations from the business sector, the environmental sector and the human rights movement founded the Forest Stewardship Council (FSC) in Toronto (Kern et al., 2001; Meidinger, 2002). Today, its headquarters are in Bonn, Germany. ${ }^{8}$ The main merit of the council is the design of a forest certification program, based on FSC values, criteria and standards and recognizable through its trademark.

The overall aim of the FSC is to stop large-scale deforestation and unsustainable forestry around the world by certifying those management practices which enhance the conservation and sustainable use of forests. After certification, timber producers may use the FSC trademark, so that wood processors and consumers can recognize this timber. With that, the FSC promotes sustainable forestry through the market mechanism. Therefore Cashore (2002) labels the FSC forest certification program as a 'non-state market-driven' governance system. This system is based on ten principles (Meidinger, 2002): forest management, property rights, rights of the local community, labor rights, sustainability, ecology and biodiversity, planning, control of adverse social and ecological effects, conservation of forests with high ecological

\footnotetext{
${ }^{8}$ Source: www.fsc.org
} 
value, and plantation. These principles are elaborated upon in a number of more practical criteria.

FSC standardization can follow two routes, the national or the global one (Kern et al., 2001). Either national sustainable forestry standards can be developed, e.g. by national NGOs and businesses (and in co-operation with governments), which at a later stage apply for FSC accreditation. Or national standardization groups immediately take the global FSC principles and guidelines as the starting point to formulate their own standard, adapted to national circumstances. In that sense, the FSC certification program is quite flexible. Besides the accreditation of national initiatives and standards, the FSC also operates as an accreditation organization for certifiers and verifiers (Cashore, 2002; Kern et al., 2001). In order to be able to monitor and enforce in a credible and trustworthy way, an independent system has been set up by the FSC. This means that certification and verification are undertaken by independent private organizations. So far, the council has accredited 13 independent bodies, from KPMG in Canada, SKAL in the Netherlands to Smart Wood in the USA. ${ }^{9}$

Although we are dealing with standardization in this section too, it is important to note the differences with the EMS standards of the previous section. Firstly, whereas the EMSs were designed by business alone (with some input of governments), the FSC certification program and its national standards have been designed by alliances of NGOs and business organizations. Here the input of civil society has been substantial. Secondly, the EMS standards apply to environmental management processes in firms and organizations, whereas the FSC standards apply to the environmental and social quality of the timber production chain. However, to prevent confusion, FSC standards are not product standards in the strict sense, because a FSC labeled product (e.g. garden furniture) has the same quality as a nonlabeled product (at least in principle). The difference is that the production processes of these products are of a different quality. Hence, ISO, RCI and FSC are all process standards, but the former two relate to management processes in organizations, whereas the latter refers to processes in a production chain. Thirdly, ISO and RCI are both standards which give certified organizations the right to carry their logos, whereas the FSC also includes a product trademark. With that, FSC also addresses individual consumers. Finally, the FSC is characterized by an unique democratic structure (Meidinger, 2002). The core decision-making body is the General Assembly, with three chambers - economic, social, environment - and with a Northern and Southern section in each of these. All these chambers and sections have equal voting rights. In contrast, decision-making in ISO and RCI are characterized by 'elitist professionalism' and 'limited stakeholder involvement'.

The FSC initiative has, according to several observers, been relatively successful (Kern et al., 2001). It started in Mexico in 1991, where a forest area of nearly 90.000 ha. was certified. Today, about 3400 companies and about 500 forest areas in 55 countries around the world have been certified. This amounts to 37 million ha. in total, which is 8 times the size of the Netherlands. ${ }^{10}$ In some countries, the forest area certified even exceeds the size of $25 \%$ of the total area (e.g. Sweden, Poland and UK). To mention another success indicator: about $8 \%$ of the Dutch timber market, both primary and secondary products, was certified in 2003 . Yet one should not exaggerate the FSC's success. A market share below $10 \%$ in all countries involved (and below 1\% in most of these) still implies a marginal market position. Also, mainstream industry has challenged the appropriateness of the FSC standard for forest management. ${ }^{11}$

\footnotetext{
${ }^{9}$ Source: www.fsc.org

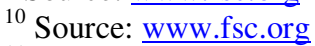

${ }^{11}$ Source: $\underline{\text { ww.pefc.org }}$
} 
From a business perspective, the standard has been based on environmental and social ethics rather than on expertise with regard to economically viable forestry. As a consequence, the FSC standard has been challenged by other types of standards. Examples are the Sustainable Forestry Initiative (SFI) of the American Forest and Paper Association and the Pan-European Forest Certification (PEFC), initiated by European forest owners and companies in the context of the intergovernmental Pan-European Helsinki process (Cashore, 2002; Meidinger, 2002). ${ }^{12}$ These business-originated standards come close to ISO-type environmental management systems and are therefore less demanding than FSC.

Given the above developments and characteristics of the FSC initiative, with what type of arrangement are we dealing with? As far as publicness is concerned, one has to conclude that this criterion amounts to 'minimal', as the FSC is a private initiative. Yet the group of active participants is not homogenous, as was in the previous case, because both NGOs and BINGOs have been involved. Overall, the inclusiveness of the initiative has been extensive, as both national and international initiatives ultimately culminated in the emergence of the FSC. Moreover, all stakeholders have in principle access to democratic decision-making. Externally, though, access has been limited, given the relatively low numbers of consumers and producers which make use of or are attracted by the FSC standard. Obviously, economic constraints at both sides prevent a massive embrace. Delegation, finally, has been substantial, as policy formulation and accreditation are the authority of the FSC General Assembly, whereas certification and verification have been delegated to third parties, who do audits in the field and may award or withdraw a certification.

To conclude, the FSC global governance arrangement of sustainable timber production is characterized by 'delegated global transnationalism' (for this categorization: see KoenigArchibugi, 2002).

\section{Conclusion}

The recent history of global environmental governance (GEG) shows substantive roles for and substantial regulatory power by non-state actors (NSAs), both NGOs and business. The cases dealt with in this chapter - biodiversity \& biosafety, environmental management systems and sustainable forestry - substantiate this claim. With that, many of the arguments from the 'new' governance literature are to be confirmed. Yet these arguments should be put into perspective. 'Old', state-oriented governance has not disappeared at all nor is 'new' governance necessarily 'new'. This is particularly shown by the biodiversity/biosafety case, a domain which is still mainly intergovernmental in nature (at least formally), while NSAs such as IUCN - have (informally) always played key-roles. In case we observe 'new' governance, the regulatory arrangements involved can be very different. The case of forestry shows a number of certification programs, among which the FSC is an example of a transnational, multi-stakeholder, market-driven governance system. In contrast, most environmental management systems are 'monopolist' business initiatives. To conclude, we do not observe a diachronic shift from government to governance in the global environmental arena, but the development of a 'multi-rule' system, in which different governance arrangements - characterized by more or less publicness, inclusiveness and delegation emerge, interact and (partially) fuse.

\footnotetext{
${ }^{12}$ Additional source: www.pefc.org
} 


\section{References}

Albrow, D. (1996), The Global Age. State and society beyond modernity. Oxford: Polity Press.

Arts, B. (2001), International Policy Arrangements of State and Non-State Actors. In: B. Arts, M. Noortmann and B. Reinalda (eds.), Non-state Actors in International Relations. Aldershot: Ashgate, 41-58.

Arts, B. (1998), The Political Influence of Global NGOs. Case Studies on the Climate and Biodiversity Conventions. Utrecht: International Books.

Arts, B. (1994), The Survival of the Fittest? The North-South power struggle in the formation of the Convention on Biological Diversity. In: F. Schuurman (ed.), Current Issues in Development Studies. Global Dimensions of Agency and Structure. Saarbrucken: Dreitenbach Publ., 1994, 309-365.

Arts, B. and S. Mack (2003), Environmental NGOs and the Bio-safety Protocol. A case study on political influence. European Environment - The Journal of European Environmental Policy, 13(1), 19-33.

Arts, B., M. Noortmann and B. Reinalda, eds. (2001), Non-state Actors in International Relations. Aldershot: Ashgate.

Bendell, J., ed. (2000), Terms of Endearment. Business, NGOs and Sustainable Development. Sheffield: Greenleafe Publ.

Bouwer, K. (1985), Grensoverschrijdende milieuproblemen in een geografisch kader. Geografisch Tijdschrift, 19, 15, 385-398.

Bovens, M. et al. (1995) De verplaatsing van de politiek. Een agenda voor democratische vernieuwing, Amsterdam: Wiardi Beckman Stichting.

Burhenne-Guilmin, F. and S. Casey-Lefkowitz (1992), The New Law of Biodiversity. In: G. Handl (ed.), Yearbook of International Environmental Law. London: Graham \& Trotman/Martinus Nijhof, pp. 43-59.

Caldwell L. (1990), International Environmental Policy. Emergence and Dimensions. Durham and London: Duke University Press.

Cashore, B. (2002), Legitimacy and the Privatization of Environmental Governance: How Non-State Market- Driven (NSMD) Governance Systems Gain Rule-making Authority. Governance, 15(4), pp. 503-529.

Clapp, J. (2002), Transnational Corporate Interests and Global Environmental Governance Negotiating Rules for Agricultural Biotechnology and Chemicals. Paper Prepared for ISA, New Orleans, March 2002 (citation permitted by author).

De Bievre, D. (2002), The WTO and Domestic Coalitions : The Effects of Negotiations and Enforcement in the European Union. Florence: Diss. European University Institute.

Depledge, J. (2000), 'Rising from the Ashes: The Cartagena Protocol on Biosafety', Environmental Politics, Vol.9. No.2. Summer 2000, pp.156-162.

Dicken, P. (1998), Global Shift: Transforming the World Economy. London: Chapman.

Driessen, P.P.J. and P. Glasbergen, eds. (2002), Greening Society. The Paradigm Shift in Dutch Environmental Politics. Dordrecht: Kluwer Academic Publ.

Dubbink, W. (1999), Duurzaamheid als patstelling. Over de onvriendelijke betrekkingen tussen openbaar bestuur, markt en 'civil society'. Delft: Eburon.

Furtak, F. T. (1997), Nichtstaatliche Akteure in den internationalen Beziehungen : NGOs in der Weltpolitik. München: tuduv-Verl.-Ges., Reihe Politikwissenschaft, nr. 73.

Gilpin, R. (2002), A Realist Perspective on International Governance. In: D. Held and A. McGrew, eds. (2002), Governing Globalization. Power, Authority and Global Governance. Cambridge: Polity Press, pp. 237-249.

Glowka, L., F. Burhenne-Guilmin and H. Synge (1994), A Guide to the Convention on Biological Diversity. Gland: IUCN.

Goetsch, D. L. and S. B. Davis (2001), ISO 14000 Environmental Management. Upper Saddle River: Prentice Hall.

Gunningham, N., P. Grabosky and D. Sinclair (1998), Smart Regulation, designing Environmental Policy. Oxford: Oxford University Press.

Hajer, M.A. (1995), The Politics of Environmental Discourse. Ecological Modernization and the Policy Process. Oxford: Oxford University Press.

Hajer, M.A. (2000), Politiek als vormgeving, Amsterdam: Vossius AUP. 
Held, D. and A. McGrew, eds. (2002), Governing Globalization. Power, Authority and Global Governance. Cambridge: Polity Press.

Héritier, A. (2001), New modes of governance in Europe : policy-making without legislating? Bonn: MPP Preprint / Max-Planck-Projektgruppe Recht der Gemeinschaftsgüter, nr. 01/14.

Héritier, A., ed. (2002), Common Goods. Reinventing European and International Governance. Lanham: Rowmand \& Littlefield

Hewson, M. and T. Sinclair, eds. (1999), Approaches to Global Governance Theory. Albany: State University of New York Press.

Higgott, R. A., G. Underhill and A. Bieler, eds. (2000), Non-State Actors and Authority in the Global System. London, etc.: Routledge, 2000.

Hirst, P. (2000), Democracy and Governance. In: J. Pierre, ed. (2000), Debating Governance. Authority, Steering and Democracy. Oxford: Oxford University Press, pp. 13-36.

Hooghe, L. and G. Marks (2001), Multi-level Governance and European Integration. Lanham, etc.: Rowman and Littlefield.

Humphreys, D. (1996), Forest Politics - The Evolution of International Co-operation. London: Eartchscan.

Hurrell, A. and B. Kingsbury, eds (1992), The International Politics of the Environment. Oxford: Clarendon Press.

Kern, K. et al. (2001), Policy Convergence and Policy Diffusion by Governmental and NonGovernmental Institutions - An International Comparison of Eco-Labeling Systems. Berlin: WZB Discussion Paper.

Kickert, W., E. Klijn and J. Koppejan, eds. (1997), Managing Complex Networks. Strategies for the Public Sector. London: SAGE.

Knill, C. and D. Lehmkuhl (2002), Private actors and the state: Internationalization and changing patterns of governance. Governance - An International Journal of Policy and Administration, 15 (1): 41-63.

Koenig-Archibugi, M. (2002), Mapping Global Governance. In: D. Held and A. McGrew, eds. (2002), Governing Globalization. Power, Authority and Global Governance. Cambridge: Polity Press, pp. 46-70.

Kolk, A. (2000), Economics of Environmental Management. Edinburg: Pearson Education Ltd.

Kolk, A. (1996), Forests in International Environmental Politics - International Organisations, NGOs and the Brazilian Amazon. Utrecht: International Books.

Lovelock, J.E. (1979), Gaia: a new look at life on earth. Oxford: Oxford University Press.

McCormick, J. (1989), The Global Environmental Movement. London: Belhaven Press.

Meidinger, E.E. (2002), Law making by Global Civil Society: The Forest Certification Prototype. Paper prepared for the International Conference on Social and Political Dimensions of Forest certification, University of Freiburg, Germany, June 2001.

Mol, A.J. (2001), Globalization and Environmental Reform. The Ecological Modernization of the Global Economy. Cambridge, Mass: MIT Press.

Nye, J.S. and J.D. Donahue (2000), Governance in a globalizing world. Washington: Brookings Institution Press.

O'Connor, J.A., Responsible Care, Doing the right thing. Canadian Chemical Producers' Association. Source: www.ccpa.ca.

Peters, B.G. (2000), Governance and Comparative Politics. In: J. Pierre, ed. (2000), Debating Governance. Authority, Steering and Democracy. Oxford: Oxford University Press, pp. 36-54.

Pierre, J., ed. (2000), Debating Governance. Authority, Steering and Democracy. Oxford: Oxford University Press.

Reinalda, B. (1997), Private in Form and Public in Purpose: (I)NGOs as Political Actors in World Politics. Paper for the ECPR 25th Joint Sessions of Workshops, Bern, Switzerland, March 1997.

Rhodes, R.A.W. (2000), Governance and Public Administration. In: J. Pierre, ed. (2000), Debating Governance. Authority, Steering and Democracy. Oxford: Oxford University Press, pp. 54-91.

Rosenau, J.N. (2000), Change, Complexity, and Governance in a Globalizing Space. In: J. Pierre, ed. (2000), Debating Governance. Authority, Steering and Democracy. Oxford: Oxford University Press, pp. 167-201. 
Rosenau, J.N. and Czempiel, eds. (1992), Governance without government: order and change in world politics. Cambridge: Cambridge Univ. Press.

Rowlands, I.H. (1995), The politics of global atmospheric change. Manchester: Manchester University Press.

Steger, U. (2000), Environmental management systems: empirical evidence and further perspectives. European Management Journal, 18(1), 23-32.

Strange, S. (1996), The Retreat of the State. The Diffusion of Power in the World Economy. Cambridge: Cambridge University Press.

Thompson-Feraru, A. (1974), Transnational Political Interests and the Global Environment, International Organization, Vol. 28, No.1, 1974, pp. 31-60.

UNEP (United Nations Environmental Programme) (1992), The Text of The Convention on Biological Diversity. Geneva.

Van Kersbergen, K., R.H. Lieshout and G. Lock (1999), Expansian and Fragmentation. Internationalization, Political Change and the Transformation of the Nation State. Amsterdam: Amsterdam University Press.

Van Kersbergen, K. and F. van Waarden (2001), Shifts in Governance: Problems of Legitimacy and Accountibility. Den Haag: SSRC/MA

Van Tatenhove, J., B. Arts and P. Leroy, eds. (2000), Political Modernization and the Environment. The Renewal of Policy Arrangements. Dordrecht: Kluwer Academic Publishers.

Vig, N.J. and R.S. Axelrod, eds. (1999), The Global Environment. Institutions, Law, and Policy. London: Earthscan.

Waters, M. (1995), Globalization. London: Routledge.

WCED (World Commission on Environment and Development) (1987), Our Common Future. Oxford: Oxford University Press.

Weale, A., The new politics of pollution, Manchester: Manchester University Press.

Weterings, M. (forthcom., 2005), De Chemie van Milieuzorgsystemen. Master Thesis Business Administration, Radboud University, Nijmegen.

Weiss, T. and L. Gordenker, eds. (1996), NGOs, the UN and Global Governance. London: Boulder.

Willetts, P., ed. (1986), The consciousness of the world: the influence of non-governmental organisations in the UN system. London: Hurst \& Company.

Yearley, S. (1996), Sociology, Environmentalism, Globalization. London: SAGE. 